УДК 94(477): 658.1148

\title{
ПРОФСПІЛКИ ТА БЕЗПЕКА ПРАЦІ У ПРИЗМІ ПОЛІТИЧНИХ ВИКЛИКІВ «ВІДЛИГИ»
}

\section{Докашенко Віктор}

Розглядаються політичні аспекти діяльності професійних спілок у иарині безпеки праиі. Стверджується, що базою для політизації цьього аспекту була державна форма власності на засоби виробництва. Доводиться, щчо влада «відлиги», користуючись відвертим нехтуванням проблеми безпечних умов прачі з боку своїх попередників, намагалася всіляко привернути до неї увагу суспільства. При иьому свою власну турботу за безпеку праці вона підкреслено протиставляла бездіяльності сталінської команди, намагаючись отримати від иььоо політичну підтримку з боку трудящих. Необхідність останньої виводиться зі специфіки приходу владної команди до політичного керма та ї̈ перманентною боротьбою з прихильниками сталінщини. Вихідною точкою політичного аспекту проблеми автор вважає той факт, що в умовах безроздільного панування державної форми власності на засоби виробництва Конституція Української РСР гарантувала громадянам право на прачю, оголошувала ї̈ обов'язком, а гарантій безпечних умов праці при ицьому не надавала.

За твердженням дослідника, механізм реалізації владних амбіцій та завоювання нових симпатиків був прихований у розвитку ідеї розширення повноважень професійних спілок. Їхня «боротьба» за безпечні умови прачі була лише одним із фрагментів політичної стратегї владної команди. Офіційне наділення спілок державними повноваженнями та правова легалізація їхніх численних компетенцій підпорядковувалися загальній стратегічній лінії, сформульованій у Новій програмі КПРС. Зроблено висновок, щзо профспілкам вдалося значно вдосконалити систему безпеки праці, позбавивши ї старих, архаїчних форм. Крім того, нова влада змогла навіть створити в суспільстві атмосферу безперервної боротьби за покращення умов праці в усіх ланках виробництва, щуо створювало ілюзію ї̈ турботи про трудівників і позитивно впливало на ї̈ політичний імідж. Незважаючи на наявність певного позитиву в иьому прочесі, політична значущість останнього розцінюється дослідником вище за практичну.

Ключові слова: безпека праці, «відлига», профспілки, сталінізм.

«Відлига» гучно протиставила волі вождя колективну волю партії, яка, згідно $з$ партійними постулатами, «представляла» широкі верстви трудящих. Сьогодні вже не викликає жодних сумнівів те, що проголошена видозміна була виваженим пропагандистським ходом, спрямованим на становлення нової влади. Нова політична команда, що отримала ії в досить сумнівний спосіб, гостро потребувала підтримки мас. Однак, з огляду на тривале сталінське панування, домогтися цього було дуже не просто. У свідомості радянських людей з іменем «вождя» пов'язувалися всі перемоги, з перемогою над фашистською Німеччиною включно. Не стерлися в пам'яті й повоєнні щорічні сталінські знижки на продукти харчування та товари першої необхідності. Не варто скидати з рахунків і ступінь заляканості радянської спільноти, що сформувала особливо обережний характер поведінки громадян.

Можливо, саме тому нова політична команда здійснила єдиноможливий правильний вибір. Рушійною силою суспільного розвитку, за образним висло- 
вом М. С. Хрущова, вона визнала не «героя-чудотворця», а народні маси. Звідси випливала й зростаюча роль професійних спілок, яких новий лідер подавав не інакше як захисників трудівників, закликаючи їх не боятися зіпсувати відносини $з$ господарниками $[20$, с. $102 ; 110]$. Зрозуміло, що останне було ні чим іншим, як дешевим фарсом, розрахованим на отримання від робітництва політичної підтримки. В лоні цієї політики знаходилася і поставлена нами проблема. Справа в тому, що безпека праці за часів сталінщини була однією із найслабших ланок процесу виробництва. Націлюючи профспілки на іiї вдосконалення та ще й протиставляючи громадську організацію господарникам, яка ними опікувалася, владна команда розраховувала передусім на політичні дивіденди.

Анонсована тема, на нашу думку, актуалізується двома обставинами. Поперше, іiі дослідження дає змогу повніше та глибше зрозуміти природу радянського тоталітаризму, з наслідками якого ми з різним ступенем успішності боремося вже майже третину століття. По-друге, аналіз тогочасних процесів у сфері охорони праці загалом та іï безпеки зокрема дає можливість зовсім під іншим кутом подивитися на їхній стан у сьогоднішніх умовах, коли профспілки втратили майже всі важелі впливу на цей процес, залишивши, по суті, українських робітників сам на сам з підприємництвом, яке й до сьогодні так і не змогло набути цивілізованих рис. Користуючись відсутністю масового та дієвого контролю, і державні, і приватні підприємства намагаються максимально ухилитися від виконання цієї функції. Ситуація ускладнюється й тим, що значна частина трудівників офіційно на роботі не оформлена. На цю обставину 2 вересня минулого року звернув увагу новий Прем’єр-міністр України, зазначивши, що статистика працевлаштування і реальний стан справ у країні суттєво різняться [2]. Справа, звичайно, не лише у відвертому ухилянні від сплати податків, що в нинішніх умовах є суттєво важливим гальмом економічного поступу. Але не менш важливим $\epsilon$ й реальний стан безпеки праці тієї частини трудівників, які не мають офіційної угоди з підприємством.

Вагомим аргументом на користь доцільності вивчення проблеми $є$ також однобічність їі наукової розробки. По суті, зараз ми маємо лише праці, що створюють для неї загальноісторичну [30], економічну [5] та політичну канву [4]. У своій більшості вони пов'язані з іменем В. Даниленка. Втім, цей стан, за всієї поваги до новизни підходів зазначеного автора, не можна визнати позитивним, передусім тому, що висвітлення проблеми здійснюється з позиції лише однієї наукової школи. Як наслідок, втрачаються важливі дійові особи епохи. 3 поля зору авторів цієї наукової школи випадає аналіз діяльності громадських організацій, зокрема профспілок. Наприклад, до сьогодні так і не визначено роль, яку відіграла наймасовіша організація в становленні та зміцненні влади епохи «відлиги». Як на нашу думку, якби не її всебічна підтримка нової влади, то навряд 
чи сьогодні ми мали б змогу говорити про політику лібералізації взагалі. Між іншим, на пострадянському просторі $є$ досить вдалий приклад висвітлення проблеми на регіональному рівні (О. Гуменюк). Хоча від виокремлення та аналізу політичного аспекту теми зазначений автор явно ухиляється [3].

Обмеженість загальної історіографічної бази ускладнюється відсутністю комплексного дослідження з історії безпеки праці, що, з огляду на рівень промислового розвитку УРСР, чисельності робочої сили в ній, а, відповідно, й обсягу виробничих ризиків, яких вона зазнавала, навряд чи можна вважати виправданим. Тут ми маємо на увазі відсутність комплексного дослідження з правових проблем охорони праці на кшталт того, що свого часу здійснив В. Семенков на матеріалі Білоруської РСР [28].

Усе зазначене вище дає підстави для формулювання мети цього дослідження. Ї̈і ми вбачаємо у виокремленні з проблеми безпеки праці в частині профспілкових компетенцій політичного аспекту та визначення його ролі у зміцненні влади «відлиги». Для досягнення поставленої мети планується здійснити аналіз діяльності тих органів керування контролем, які, власне, забезпечували формування його політичного складника. До них дослідником зараховано передусім технічні інспекції праці, що функціонували при обласних та республіканській радах, виконуючи функцію державного контролю за безпечністю праці та комісій з охорони праці, які чинили ці дії при фабрично-заводських та місцевих комітетах (ФЗМК), реалізовуючи їх на громадських засадах.

Аналіз окресленої проблеми логічно почати з уточнення понятійного апарату, що дасть змогу точніше визначитися як з предметом, так і з об'єктом дослідження. Незважаючи на те, що поняття охорони та безпеки праці на виробничому і побутовому рівнях вже мало не набило оскомину, між іншим, на щаблі науки ще часто-густо знаходимо їхні непоодинокі суперечливі трактування, що значно ускладнює точне визначення предмету цієї розвідки. Не заглиблюючись у теорію питання, візьмемо за основу формулювання, наведене В. Семенковим у вже згадуваній нами монографії. Важливою підставою для цього $є$ те, що зазначена праця $\epsilon$ продуктом епохи, а її перше видання побачило світ в окреслені нами хронологічні межі. 3 урахуванням цієї обставини вона перетворюється на надзвичайно важливе джерело дослідження, яке дає змогу сучаснику побачити процес у тому світлі і під таким кутом, в якому бачили його наші попередники.

Отже, зазначений автор під поняттям «охорона праці» розуміє: норми і правила з техніки безпеки та промислової санітарії, заходи індивідуального захисту від професійних захворювань та виробничих травм, спеціальні норми і правила 3 охорони праці жінок, підлітків і осіб зі зниженою працездатністю, норми, що регулюють діяльність державного нагляду та громадського контролю [28, 27-28]. 
3 цього об'ємного переліку предметом дослідження нами обрані лише політичні аспекти безпеки праці, що реалізовувалися під патронатом профспілок. У такому випадку охорона праці, що здійснювалася під їхнім патронатом, постає його об'єктом.

Враховуючи зазначене, спробуємо визначити вихідну точку політичного аспекту проблеми. На нашу думку, вона має відбиватися у Конституції при регламентації прав громадян і встановленні характеру взаємовідносин із державою. Позаяк безпека праці є важливою складовою процесу виробництва, нагальним завданням постає визначення власника засобів виробництва, що, з огляду на політизованість питання, є справою, як може здатися на перший погляд, не такою вже й простою. Здавалося б, саме той, хто є власником, і має нести відповідальність за безпечність умов праці. Втім, упорядники Основного Закону Української РСР (1937р.), слідом за їхніми колегами союзного рівня, тут явно «напускали туману». Засоби виробництва вони зарахували до соціалістичної власності, яка перебуває у формі або державної, або колгоспно-кооперативної власності (ст. 5). Перша тлумачиться одночасно як «всенародне добро». По суті, Конституція точної відповіді на питання, хто ж саме володіє заводами, фабриками та всім іншим добром, так і не дас. Згідно з Основним законом, все перелічене перебувало у власності держави, але, разом із тим, воно залишалося і «всенародним добром» (ст. 6). Сутність останнього в Конституції не розкривалася. Безсумнівно, інтереси держави та інтереси народу їі творцями ототожнювалися, що явно не відповідало реальному стану справ.

Окрім того, такий стан справ забезпечував небезпечну близькість політики до виробництва. Сполучником поставала державна форма власності, яка й політизувала виробництво, змінюючи формулу його функціонування з «виробництво для виробника» на «виробництво для держави». Останнє ставило з ніг на голову його первісну мету. Конституція УРСР повністю забезпечувала політичний бік питання. Ї̈ї ст. 117 надавала право «...на отримання гарантованої роботи з оплатою праці у відповідності з їі кількістю та якістю», ст. 112 - оголошувала працю «обов'язком і справою честі кожного, здатного до праці громадянина за принципом: «хто не працює, той не їсть» [10]. Отже, по суті маємо конфлікт інтересів: фактичний власник засобів виробництва гарантує своїм громадянам право на працю, навіть оголошує його «обов'язком», але при цьому чомусь не гарантує іiї безпеки.

На нашу думку, мотивів такого нонсенсу декілька. Допускаємо, що вагомою причиною цього був мобілізаційний характер радянської економіки, заснований на відсталій техніці та технологіях, які підштовхували безпосереднього товаровиробника на всілякі «трудові подвиги» в ім’я виконання та перевиконання дер- 
жавних планів. Уже давно ні для кого не є секретом те, що кожен із таких починів створював серйозний технічний ризик, перманентно загрожуючи аваріями на виробництві та навіть можливими людськими жертвами. Звичайно, у повоєнний період вже не використовували таких одіозних форм новаторства, як збільшення поду доменної печі, свого часу начебто запропонованого маріупольським металургом М. Мазаєм, чи швидкісного пересування залізничних рухомих складів зі значним збільшенням навантаження на вісь, який нав'язувався слов'янським машиністом П. Кривоносом.

Але нікуди не поділися інші форми змагальності та рухи новаторів, які підвищували інтенсивність праці, а отже, збільшували вірогідність відповідних ризиків для життя робітників. Є всі підстави вважати, що за цих обставин держава не могла взяти на себе відповідальність за можливі загрози та конституційно гарантувати безпечні умови праці. Склалася дивна ситуація: власник виробництва всіляко заохочував трудовий героїзм, але гарантій його безпеки при цьому не надавав. При визначенні причин зазначеного не варто також скидати з рахунку нівелювання відчуття господаря виробництва у робітників, яке було незмінним супутником державної форми власності, а також безлад та безгосподарність, які їі супроводжували. Звичайно, за цих обставин давати конституційні гарантії безпеки праці з боку держави було б вкрай поспішним і геть невиваженим кроком.

Формальним приводом політизації безпеки праці, як і охорони праці загалом, є характерна для моделі радянського тоталітаризму передача державних функцій професійним спілкам, що розцінювалося не інакше як найвище досягнення радянської демократії. Логіка правників того часу була достатньо простою: оскільки всі заходи радянських профспілок у галузі господарської та культурно-виховної роботи виражали класові, читай політичні інтереси трудящих СРСР, то й діяльність професійних спілок, які представляли їхні інтереси, не могла мати іншого характеру, ніж політичний $[29,10]$. При цьому принагідно зазначимо, що ні в сталінському статуті профспілок, прийнятому в 1949 р., ні в його першій постсталінський редакції (1954р.) не було навіть натяку про передачу державних функцій громадській організації. Цей широкий жест є виключно заслугою політичної команди М. Хрущова. У повній відповідності з формулюваннями грудневого (1957р.) Пленуму ЦК про зростання ролі профспілок ця новація з'явилася і в редакції їхнього статуту, що був прийнятий в 1959 р. Ця обставина, власне, й обумовила появу в основоположному документі спілок фразу, що «вони все ширше залучаються до розв'язання питань державного, господарського і культурного будівництва $[33,5]$. Ми далекі від думки, щоб віднести цитоване до ініціативи самих профспілок. Це починання, звичайно ж, належало 
партії. Його озвучив М. Хрущов у своїй доповіді на XXI з’їзді КПРС: «Розширення функцій громадських організацій у вирішенні державних питань» він відніс до числа найважливіших політичних завдань [11, 20-21].

Формально, передача деяких державних функцій профспілкам дійсно може виглядати як ознака наближення комунізму. Принаймні, радянським громадянам ця думка наполегливо нав'язувалася. В дійсності ж вони мали справу з технологією, привнесеною партією влади, в якій безпека праці, передана на відкуп залежним від влади і партії профспілкам, була лише однією з ії складових. Масова громадська організація була розбудована у такий спосіб, що підходила для цього ідеально. По-перше, вона офіційно визнавала керівну роль партії влади, що було гарантією iï перебування точно в межах визначеного курсу. По-друге, згідно зі своїм Статутом, спілки були єдиною громадською організацією, що мали право виступати від імені робітників і службовців перед державними і громадськими органами 3 питань праці, побуту та культури $[34,6]$. По-трете, радянські профспілки мали досить специфічну, як для громадської організації, функцію - господарську. Нам вже доводилося писати, що левова частка їхньої статутної діяльності припадала якраз на сферу виробництва [6]. 3 огляду на ці обставини, передача профспілкам нагляду і контролю за безпечними умовами праці з погляду інтересів влади виглядає цілком логічною.

Політична команда М. Хрущова прийшла до влади в той час, коли ця сфера діяльності профспілок вже була узвичаєним фактом. Тобто, перед тогочасними очільниками не стояло завдання пошуку організації, що опікуватиметься колом цих питань. Перед ними стояло завдання дати їй новий суттєвий поштовх до діяльності, що мало підкреслити, з одного боку, бездіяльність старої влади стосовно створення безпечних умов праці та, навпаки, - підкреслити турботу про них нової. Результатом мало стати збільшення кількості політичних симпатиків, підтримки яких все більше і більше потребували нові очільники, знаходячись у стані перманентного протистояння з прихильниками «вождя народів». У грудні 1957 р. відбувся Пленум ЦК, на якому була прийнята своєрідна програма зростання ролі профспілок у житті суспільства.

Важливою її складовою стала безпека праці. Для проведення ретельнішого аналізу Постанови пленуму та, відповідно, посилення аргументації власних висновків нами їі було розділено на форми діяльності профспілок: «господарську», «умови праці», «виховну» та «організаційну». Саме за цими формами діяльності й було здійснено підрахунок кількості понять, що характеризували ту чи іншу сферу діяльності. Частота їхнього використання в Постанові засвідчувала ступінь їхньої ваги для партійного істеблішменту вищої ланки. В «умовах праці» їх виявилося найбільше - 41, що складає майже 32 \% від їхньої загальної 
кількості $[6,59]$. Зазначене дає підстави зробити припущення, що саме «умови праці» були тим важелем, який, у випадку серйозних зрушень з їхнього вирішення, міг би допомогти прийдешнім очільникам закріпитися біля владного керма. Це достатньо чітко простежується і в змісті постанови Пленуму. Її упорядники вийшли за вузькі межі охорони праці. Підсумковий документ Пленуму зобов'язував профспілки не лише повніше використовувати свої можливості для посилення контролю за станом техніки безпеки, а й «настійливо вимагати від господарських органів безумовного виконання заходів з подальшої механізації важких і трудомістких робіт, впровадження більш досконалої технології, створення нормальних санітарних умов для всіх працюючих» [15, 221].

Навряд чи можна було знайти хоч одного робітника, якому б не сподобався цей партійний пасаж, тим більше, що стан техніки безпеки дійсно був на межі критичного. Для точного відтворення стану справ наведемо витяг 3 протоколу засідання президії Укрпрофради від 19 серпня 1955 р., на якому виступив 3 доповіддю заступник міністра вугільної промисловості республіки Івонін (ініціали в документі відсутні). Розглядалося питання про стан охорони праці у вугільній промисловості республіки та заходи з його поліпшення. Отже, далі мовою протоколу: «головне управління «Східдонбасвугілля» дозволило експлуатацію 16 лав 3 порушенням правил техніки безпеки», «у тресті «Артемукргеологія» медогляд пройшли лише 30 \% робітників», «у першому півріччі 1955 р. 31407 заходів 3 вентиляції та техніки безпеки виконано лише 761», «на багатьох шахтах причини нещасних випадків розслідуються 3 порушеннями встановлених термінів. $€$ факти приховування травматизму. Обставини і причини нещасних випадків господарниками на місцях не з'ясовуються, винні особи до відповідальності не притягуються», «на шахті XIX з'їзду КПРС тресту «Ворошиловвугілля» головний інженер тов. Ільїн (ініціали в документі відсутні) не лише приховує виробничий травматизм, а й огульно звинувачує в нещасному випадку самих робітників»... [26, 2-5]. До відома попутно зазначимо, що цитований нами протокол вже був попередньо ретельно вивірений апаратниками Укрпрофради, що дає підстави зробити припущення, що до нього не могли потрапити інші, ще більш кричущі та дискредитуючі систему господарювання факти.

Вугільна промисловість була не єдиною галуззю, що мала такий комплекс проблемних питань. Така ж ситуація зі станом техніки безпеки мала місце і в інших галузях виробництва. В 1950 р., наприклад, Й. Сталін навіть підписав Постанову Ради Міністрів СРСР «Про заходи з покращення стану охорони праці та техніки безпеки на залізничному транспорті», в якій наводилися вражаючі цифри втрачених робочих днів на ряді залізниць СРСР - 289 на 1 тис. робітників. Це означає, що з кожної тисячі працівників галузі майже третина перебува- 
ла на лікарняному. Про всю серйозність ситуації свідчить і додаткове фінансування галузі, здійснене вже після прийнятого бюджету країни, що було можливим лише за безпосереднього втручання вищих посадових осіб держави. Тоді цільовим призначенням на охорону праці на залізницях було виділено майже 110 млн рублів. Із них на Донецький округ залізниць (Ясинувата) - 9 млн, Південно-Західний (Київ) - 6,5 [13].

Враховуючи такі провали у сфері безпечності праці, новій владній команді було б гріх ними не скористатися. Але для цього їй треба було передусім суттєво оновити механізм її забезпечення. Для цього у травні 1958 р. було створено Державний комітет Ради Міністрів Української РСР з нагляду за безпечним веденням робіт у промисловості та гірничому нагляді [14], однак його діяльність не входить до кола наших наукових інтересів, оскільки в цій площині нас цікавить діяльність наймасовішої громадської організації. Повноваження з охорони праці та техніки безпеки вона отримала внаслідок прийняття Радою Народних Комісарів СРСР та ВЦРПС спільної Постанови від 10 вересня 1933 р. за № 1952 «Про порядок злиття Народного Комісаріату праці з Всесоюзною Центральною Радою професійних спілок». Згідно з цим документом інспекція праці організовувалася за галузевим принципом при всіх центральних комітетах і їхніх місцевих органах. За порушення законодавства про працю за нею зберігалося право накладання штрафів. Правила та норми з техніки безпеки та промислової санітарії встановлювали центральні комітети відповідних профспілок за узгодженням із зацікавленими відомствами [16].

Отже, на час «відлиги» в країні вже мала місце широко розгалужена система контролю за станом техніки безпеки. Що ж до розмежування державного нагляду і громадського контролю в царині профспілок, то фахівці того часу в своїй переважній більшості дійшли висновку, що ці відмінності мали здебільшого умовний характер [28, 221]. Нами вони розмежовуються (знову ж таки умовно) на державний контроль, який виконувала технічна інспекція при відповідних профспілкових комітетах, а потім радах, і громадський, що знаходився в компетенції ФЗМК. Отже, новій владі для досягнення бажаного результату залишалося лише підвищити ефективність уже діючої системи. Ця робота здійснювалася через розширення повноважень профспілок у всіх напрямах їхньої роботи. Безпека праці була лише одним із них. Зокрема, ще майже за півроку до грудневого Пленуму ЦК, який для радянських спілок був доленосним, у серпні 1957 р. ВЦРПС затвердила дуже важливе з погляду політики «Положення про республіканську, крайову і обласну раду профспілок». По суті, це був перший документ, спрямований на підвищення значущості наймасовішої організації.

Положення не лише регламентувало права та обов'язки профспілкових рад, а й, на нашу думку, значно збільшувало їхню політичну залежність від КПРС. 
Для останньої ситуацію значно полегшувало те, що обласні та республіканські ради, об'єднавши під своєю орудою всі профспілкові організації областей та республіки (1948р.), були розбудовані за принципом паралелі до обласних комітетів партії та її ЦК. У цій ситуації нова політична команда, наділяючи профспілки все новими й новими повноваженнями в зворотній пропорції, збільшувала їхню залежність від себе. Адже зростання прав неодмінно вело й до зростання контролю над їхнім використанням. Отже, чим більше повноважень отримували профспілкові комітети, об'єднані обласними радами, тим більшою була залежність від обласного чи республіканського партійного центру.

Відповідно до Положення обласні ради профспілок отримали в обов'язок здійснення контролю за станом техніки безпеки та виробничої санітарії, контролю адміністрації за розподілом фондів на спецодяг. Вони ж керували роботою технічної інспекції та брали участь у заходах із покращення умов праці. Рада профспілок отримала навіть право на призупинення діяльності окремих підрозділів виробництва, що не відповідали нормам техніки безпеки та промислової санітарії $[24,2 ; 4]$. Втім, розширення цих прерогатив здійснювалося у досить специфічний спосіб. Передусім зазначимо, що темпи розширення були різними: відносно обласних і республіканської рад вони були значно вищими, а щодо ЦК галузевих спілок, - навпаки, нижчими [7]. Як приклад, у частині техніки безпеки, згідно з рішенням VI пленуму ВЦРПС, технічна інспекція в 1957 р. була передана з відання ЦК галузевих спілок до компетенції обласних рад. Для оперативного керівництва ними там створювалися відділи або інспекторські групи. Їм же було передано і страхових лікарів профорганізацій [14, 227]. Галузевий принцип діяльності страхових лікарів (з грудня 1957 р. довірених лікарів) було збережено лише на залізничному транспорті, авіаційному, морському та річковому флоті [21].

Причину цих маніпуляцій ми вбачаємо, передусім, в тому, що обласним комітетам партії зручніше було контролювати облпрофраду, яка об'єднувала всі профспілки області, аніж розрізнені галузеві спілки, які не мали структури, аналогічної партійній. Причому, йдеться не лише про контроль за станом техніки безпеки, що, загалом можна зрозуміти та досить легко пояснити. Йдеться також про контроль за приховуванням від широкої громадськості фактів великих аварій, особливо тих, що спричинили людські жертви. Враховуючи високий рівень інформованості технічних інспекторів та довірених лікарів, низький рівень стану техніки безпеки праці, а також замкнутість радянського суспільства, така пересторога з боку інтересів влади не виглядає зайвою. Ось чому час від часу й виникали ситуації, що вражали гіркотою своєї абсурдності. Наведемо одну з них. 17 листопада 1963 р. на горлівській шахті «Комсомолець» трапилася велика 
аварія, викликана раптовим викидом метану. Загинуло 11 шахтарів, ще 18 осіб отримали тяжкі травми. Однак жодної інформації щодо цього ні центральна, ні місцева преса не подали. Проте, в той же день «Известия» під заголовком «Жертвы катастрофы» помістили замітку про обвал, що стався на бельгійській шахті «Сен-Маргеріт», де на глибині 700 метрів загинуло 2 гірники [1, 157-158]. Цілком очевидно, що цей факт, яскраво описаний Першим секретарем ЦК Компартії України П. Шелестом в листі до ЦК КПРС, додаткового коментаря не потребує.

Утім, піднята хвиля «боротьби» за безпечні умови праці, активована цими документами, хоч і носила характер кампанії, але результати давала доситьтаки помітні. Наприклад, технічна інспекція праці, що діяла при Вінницькій облпрофраді, а це всього 5 осіб, у 1958 р. за порушення правил і норм техніки безпеки та промислової санітарії наклала на посадових осіб стягнення у вигляді штрафів на суму 23700 руб., що за масштабом цін того часу було величезною сумою (середня заробітна плата складала 767 руб. на місяць, або, за вигаданим курсом того часу, 191 долар [32]). Але головним було інше. Набагато важливішим з погляду політики було те, що чотирьох посадових осіб з цих же причин було звільнено з роботи, а одинадцять - засуджено судом. І це при тому, що розгляд певної частини справ зі смертельними наслідкам ще знаходився в судових інстанціях $[18,3]$. При цьому принагідно зазначимо, що за попередній рік сума штрафів була чи не втричі меншою, а судові рішення взагалі були відсутні. Враховуючи упередженість радянського робітництва до керівного складу підприємств, такі рішучі дії, безсумнівно, мали політичний підтекст і додавали симпатиків новій владі, яка виступила ініціатором цієї «боротьби».

Незважаючи на всі видимі зрушення в цій сфері, ми далекі від того, щоб визнати організацію контролю за безпекою праці бездоганною. 3 огляду на документи, на заваді цьому стояв передусім занижений штат відділів та груп технічної інспекції в облпрофрадах. Працюючи з документами профспілок, на цю обставину ми спочатку не звернули належної уваги, зарахувавши іiї до числа бюрократичних і безпідставних звернень, якими часто-густо «грішили» облпрофради, намагаючись збільшити чисельність працівників. Однак та частота, 3 якою вони зверталися з цією проблемою, та глибина аргументації змусили дослідника уважніше поставитися до цього питання. Виявилося, що в більшості випадків такі прохання були достатньо вмотивованими. Наприклад, головний технічний інспектор Вінницької області в своїй інформації доводив необхідність збільшення штатних одиниць інспекторів розрахунком їхнього робочого часу. Він констатував, що малочисельність інспекторів через їхню перевантаженість не надавала змоги навіть підготувати інспекторів на громадських засадах, 
на яких робили спроби перекласти значну частину тягаря в створенні безпечних умов праці. Насамкінець було зроблено абсолютно приголомшливий висновок: «Малочисельність інспекторів призвела до того, що останнім часом інспекція займається виключно розслідуванням нещасних випадків з тяжкими наслідками, полишивши іншу необхідну роботу» $[9,14]$. До іншої роботи, зокрема, належала профілактика порушень через створення інституту громадських інспекторів, які повинні були створити атмосферу нетерпимості до щонайменших порушень.

Чи була реакція вищого органу профспілок? Саме на цей випадок її виявити не вдалося. Однак, у протоколах засідання президії знайдено відповіді на аналогічні клопотання інспекцій праці інших областей: Дрогобицької, Волинської та Херсонської. Тут президія Укрпрофради дозволила регіональним підрозділам збільшити з тих же причин кількість інспекторів на 1-2 особи, але за рахунок їхнього скорочення в Київській, Одеській та Харківській областях. По одній особі було також доповнено їхній штат у Волинській та Кіровоградській облпрофрадах, але, знову ж таки, за рахунок скорочення цих посад у Ворошиловградській та Сталінській. Принагідно зазначимо, що й сама республіканська рада потерпала від браку інспекторського складу, бо тією ж постановою президії керівним особам доручалося звернутися до ВЦРПС з клопотанням про виділення трьох штатних одиниць для відділу технічних інспекторів Укрпрофради $[27,250]$.

Наступним кроком влади в напрямі удосконалення системи безпеки праці стало розширення прав первинних профспілкових організацій. Таким документом став Указ Президії Верховної Ради СРСР «Про права фабричного, заводського місцевого комітету професійних спілок», прийнятий у липні 1958 р. Пріоритет у цьому надзвичайно важливому документі вищого законодавчого органу СРСР було надано не проблемі безпеки праці. На першому плані постали питання участі профспілок у плануванні та реалізації виробничих планів. Питання безпеки праці посіли лише дев'яту позицію. Їх було зараховано до блоку з охорони праці, що об’єднував 8 аспектів діяльності громадської організації. Техніка безпеки була одним із них. Але це не суть важливо, важливо те, що Указ надавав профспілкам у цій сфері важливе право - контролю за діяльністю адміністрації, що перетворювало їх у важливий громадський важіль впливу [23]. На нашу думку, цим документом переслідувалася подвійна мета. По-перше, з погляду політичних інтересів влади, імплементація документа надавала змогу створити ілюзію серйозності їі намірів у забезпеченні гідних і безпечних умов праці. По-друге, Указом легітимізувалася величезна кількість профспілкових повноважень, зокрема й з безпеки праці, що давало змогу «вписати» їх у правове поле. Раніше, коли вони мали скоріше статус політичних декларацій, а їхнє становище з погляду трудового права було досить непевним. 
Могутнім каталізатором політизації проблеми безпеки праці стало рішення XXII з'їзду КПРС про прийняття Нової програми партії, якою було офіційно взято курс на розгорнуте будівництво комунізму. Зрозуміло, що в процесі його розбудови безпеку праці треба було піднести на новий, значно вищий рівень. Не міг етап зведення підвалин комуністичної формації апріорі поєднуватися з таким високим рівнем травматизму та захворюваності, що все ще мав місце. Тим більше, що Нова партійна програма обіцяла, що при комунізмі «Праця і дисципліна не будуть тягарем для людини», а трудова діяльність перестане бути засобом для існування і «перетвориться на справжню творчість, джерело радості» $[25,275]$. Отже, політичний чинник, який значно випередив практику повсякденності, об'єктивно вимагав суттєвих змін. Це означає, що владі у сфері покращення умов праці конче необхідною була демонстрація динаміки добре помітних зрушень. Це б засвідчувало правильність обраного партією курсу та, відповідно, підтверджувало правомірність перебування при владі політичної команди М. Хрущова. Втім, початок 60-х рр. у цій царині давав досить мало підстав для комуністичного оптимізму. Рівень виробничого травматизму, зокрема зі смертельними наслідками, хоч дещо і знизився, як зазначалося в спільній Постанові Ради Міністрів СРСР і ВЦРПС, прийнятій невдовзі після завершення роботи партз'їзду (23 січня 1962 р.), але все одно залишався високим [12, 23].

Оскільки питання охорони праці востаннє розглядалося Радою Міністрів в 1950 р. і підписувалася ще Й. Сталіним, що переносить нас у зовсім іншу епоху, зупинимося на більш детальному аналізі політичної складової аналогічного документу, прийнятого майже 12 років поспіль його наступниками [13]. Працюючи над текстом документа, ми дійшли висновку, що нова Постанова $є$ результатом активації проблеми XXII з'їздом, а це зайвий раз підтверджує наше твердження про наявність у ній політичного підтексту. I хоча безпосереднє посилання на його рішення в документі відсутнє, причинно-наслідковий зв'язок видно неозброєним оком. По-перше, це засвідчує ту поспішність, з якою Постанова приймалася (від часу прийняття Нової партійної програми ледве минуло два місяці). Подруге, вона не містить принципово нових концептуальних рішень, або принаймні нових форм роботи, що викликає питання про причини ії прийняття. По-третє, це рішення уряду та ВЦРПС не містило конкретних вказівок на необхідність посилення фінансування цієї сфери, як це, скажімо, мало місце в сталінській постанові. Більше того, в ній зазначалося, що попри величезні асигнування, ефективність їхнього використання залишає бажати кращого. Але в такому випадку упорядникам варто було б посилатися на ретельний аналіз причин такого стану справ. Він теж повністю відсутній.

Із вищезазначеного можна зробити висновок, що проблема безпеки праці цікавила укладачів не просто як така. Точніше сказати, не лише як така. Не менш 
важливим для них, очевидно, була ії політична складова. Це означає, що аналізована Постанова розглядалася владниками як гарний стартовий майданчик для запуску нового витка «боротьби» за безпечні умови праці. Зрозуміло, що на документ, прийнятий на такому високому рівні, змушені будуть реагувати всі без винятку господарники та чисельні профспілкові організації. Враховуючи масовість останніх, можна було очікувати, що нова фаза «битви» за безпеку невдовзі накриє всю країну та створить яскраву картинку рішучої боротьби влади за безпечні умови праці. Отже, цілком очікуваними були і високі політичні дивіденди, які мала принести ця кампанія. Чим гучнішою та масштабнішою буде нова хвиля, тим вищими мали бути політичні активи партії та влади. Виходячи $з$ прямої залежності профспілок і від однісї й від другої, прогнозовано високою мала бути їхня активність, позаяк вони відповідали за цю сферу як в державній, так і в громадській іпостасі.

За допомогою Постанови маховик «боротьби» за безпечні умови праці розкручувався, передусім, на низовому рівні виробництва, яким опікувалися профспілкові, фабрично-заводські та місцеві комітети. Вочевидь, що саме під її впливом було прийняте нове «Положення про комісію з охорони праці...», затверджене у жовтні 1963 р. постановою Президії ВЦРПС. Порівняно з аналогічним положенням зразка 1951 р., iї компетенції ставали значно глибшими та об’ємнішими. Їх, урешті-решт, позбавили дріб'язкових обов'язків, як-то контролювати наявність води в цехах, а в «гарячих» цехах - газованої води. Комісії з охорони праці, зокрема, отримали право повсюдно перевіряти стан техніки безпеки і виробничої санітарії, починаючи від виробничих місць та аж до цехів і дільниць. Крім того, вони були зобов'язані сприяти адміністрації у впровадженні нової техніки та технологій, автоматизації та механізації виробничих процесів. Вони ж робили висновок щодо ступеня провини потерпілої особи при аваріях, що значно підвищувало їхню вагу в очах робітництва, та брали участь у прийманні до експлуатації щойно завершених виробничих об'єктів. Звичайно ж, ці комісії зобов'язані були надавати допомогу громадським інспекторам, тим більше, що їхні очільники водночас були старшими громадськими інспекторами підприємства чи цеху [22, 261-262].

За логікою оповіді політичної історії в цьому місці ми повинні були б почати аналіз чисельності та діяльності громадських інспекторів, які завершували вертикаль профспілкового контролю. Однак, через абсолютно невірогідну їхню кількість, що надає профспілкова статистика того часу, змушені від цієї ідеї відмовитися. На жаль, нам не вдалося встановити їхньої реальної кількості. Певною мірою ситуацію дещо прояснила перехресна перевірка їхньої чисельності за документами різного походження: партійного та профспілкового. Схоже, що вище 
партійне керівництво республіки було не в змозі визначитися з необхідною кількістю активістів цієї ланки. Десь його можна зрозуміти, адже їхнє завищення у звітності за певних обставин могло свідчити про низький рівень стану техніки безпеки, що партійними органами вищої ланки могло бути оцінено негативно. 3 іншого боку, їхня незначна кількість могла демонструвати недостатність зусиль апарату в «боротьбі» з порушеннями правил і норм техніки безпеки. I все ж таки, найбільш вірогідна їхня кількість коливалася в районі 1 млн. Лише за 1963 р., що засвідчує звіт із навчання кадрів профспілок, було спрямовано на навчання 200 тис. громадських інспекторів, що складає близько 17 \% загальної кількості профспілкового активу $[17,1]$. За даними статзвітності цієї громадської організації, щорічно вона проводила навчання приблизно 20 \% свого активу, що в абсолютному вираженні й виводить нас на 1 мільйон чисельного складу громадських інспекторів. Але ця цифра, отримана у такий умоглядний спосіб, хоча і є досить приблизною, вона хоч якось відповідає дійсності. Профспілкова статистика виводить нас на цифру, вдвічі більшу, аж до 2 млн осіб. Багато це, чи мало? Якщо врахувати, що середньорічна чисельність робітників і службовців в Українській РСР в 1963 р. трохи перевищувала 12 млн осіб [31, 477], то виходить, що понад $16 \%$ складу робітників і службовців республіки здійснювали контроль за дотриманням безпечних умов праці. Останнє, на нашу думку, $є$ результатом успішності скоріше пропагандистської діяльності, аніж практичної роботи.

I все ж таки для повного ігнорування заслуг наймасовішої організації достатніх підстав ми не бачимо. Домогтися вагомих зрушень їй все ж таки вдалося. Нами були проаналізовані звіти технічних інспекцій ряду розвинутих у промисловому відношенні областей. Причому для дослідження використовувалися не річні звіти, які дають значно більш спотворену інформацію, а поточні, в яких вона значно ближча до реальності через зменшення тиску з боку вищих керівних органів у перших кварталах і його посилення в кінці року. Так, за першу половину 1964 р., порівняно з аналогічним періодом попереднього року, в Дніпропетровській області травматизм зменшився на 13,6 \%, у Запорізькій - на $18 \%$, у Донецькій - на 18,9 \%. Так само зменшилася і кількість травм із летальними наслідками: в Дніпропетровській - майже на $27 \%$, а в Донецькій - 7 \%. Однак ще контрастнішою виглядає картина стану травматизму в найбільш травмонебезпечній галузі республіки - вугледобувній. Якщо в 1958 р. тут кількість осіб, що постраждали на виробництві, сягала 88 482, то в 1964 р. - 44787 осіб. Тобто, число травмованих за це час зменшилося вдвічі. Крім того, якщо на шахтах УРСР в 1958 р. загинуло 1106 гірників, то в 1964 р. - 656 (40,7 \%) [19, арк. 22; $69 ; 120 ; 47]$. Звичайно, втрати людей залишалися ще неприпустимо високими, але ж і зрушення в кращий бік стали відчутними, що не могло не позначитися 
на рівні політичних дивідендів. Зиск від останніх виміряти в одиницях неможливо, але майже десятирічний термін нав'язування суспільству ідеї «боротьби» за безпечні умови праці, що здійснювалося наймасовішою організацією трудящих, безперечно, свою справу зробило.

Викладене вище дає можливість сформулювати декілька прикінцевих висновків. По-перше, професійні спілки у період, що досліджувався, значно вдосконалили систему контролю за станом техніки безпеки. Вони позбавили ії старих, архаїчних форм, характерних для сталінської доби, та прищепили їй нові, що грунтувалися на засадах радянського лібералізму. По-друге, завдяки професійним спілкам, які впроваджували ідею масового контролю, новій владі вдалося створити в суспільстві атмосферу безперервної боротьби за покращення безпеки праці на всіх ланках виробництва, що створювало ілюзію турботи влади про трудівників і позитивно впливало на ï політичний імідж. По-трете, оскільки «відлига» залишила непохитними теоретичні постулати попередників, з державною формою власності на засоби виробництва включно, вона не могла кардинально переломити ситуацію у сфері виробничих відносин, у площині якої знаходилася діяльність профспілок із досягнення безпечних умов праці. Отже, політична ефективність розцінюється нами значно вище, ніж практична. Подальше поглиблення та розширення дослідження проблеми бачимо у вивченні питань діяльності професійних спілок у сфері дотриманням трудового законодавства.

\section{Abstract}

The article studies the political aspects of the trade unions' activities in the field of labor safety. It is argued that the basis for the politicization of this aspect was the state ownership of the means of production. The power of the Thaw, using a blatant disregard for the problem of safe working conditions by its predecessors, tried to attract the attention of the society in every possible way. At the same time, Khrushchev's government stressed its own concern for labor security with the inaction of Stalin's team, trying to gain political support from the workers. The latter is driven by the author from the specifics of the ruling team's coming to the political leadership and the state of its permanent struggle with the supporters of Stalin.

According to the researcher, the mechanism of realization of power ambitions and the conquest of a new number of sympathizers was hidden in the development of the idea to expand trade unions' powers. For the ruling team their "struggle" for safe working conditions was only one of the fragments of the political strategy. The official assignment of unions to state powers and legalization of their numerous competencies were subordinated to the overall strategic line formulated in the New CPSU Program. It is concluded that in the society the new government created an atmosphere of continuous struggle for improvement of labor safety in all production units, which created the illusion of the authorities' concern for workers and positively influenced its political image.

Keywords: labor safety, Thaw, trade unions, Stalinism. 


\section{ДЖЕРЕЛА ТА ЛІТЕРАТУРА}

1. В ЦК КПСС. Письмо Первого секретаря ЦК Компартии Украины. П. Е. Шелеста. 8 апреля 1965 г. Центральний державний архів громадських об'єднань України (ЦДАГО України). Ф. 1, оп. 24, спр. 5990, арк. 157-158.

2. Виступ Прем'єр-міністра України Олексія Гончарука на каналі ICTV. 2 вересня 2019 p. URL: https://www.youtube.com/watch?v=_rqqDqknFQU (дата звернення: 14.09.19).

3. Гуменюк А. А. Охрана труда в СССР в 1953-1985 гг. (по материалам Нижнего Поволжья). Известия Саратовского университета. Серия История, Международные отношения. 2015. № 1. C. 106-114. URL: http: //nvsu.ru/ru/ otd_international/1967/1.pdf (дата звернення: 03.09.19).

4. Даниленко В. М. Політичні зміни в СРСР і Україні в період хрущовської «відлиги». Україна ХХ ст.: культура, ідеологія, політика. Київ: Ін-т історії України НАН України, 2008. Вип. 14. С. 3-17.

5. Даниленко В. М., Новохатько Л. М. Економіка України в добу десталінізації (1956-1965). Економічна історія України: Історико-економічне дослідження: в 2-х т. НАН України. Інститут історії України. Київ: Ніка-Центр, 2011. T. 2. C. $406-456$.

6. Докашенко В. М. «Відлига» в контексті розширення прав і обов’язків професійних спілок. Грані історії. Вип. 8: збірник наукових праць. Артемівськ: вид-во ГІІМ, 2015. С. 46-67.

7. Докашенко В. М. Метаморфози організаційної будови радянських профспілок (середина 50-х - середина 60-х рр. Грані історії. Випуск 6. Збірник наукових праџь. Горлівка: Вид-во ГІІМ «ДДПУ», 2013. С. 47-57.

8. Жидецький В. Ц. Основи охорони праці: підручник. Львів: Афіни, 2004. URL: https://westudents.com.ua/glavy/3379-z-stor-naglyadu-za-ohoronoyu-pratsv-ukran.html (дата звернення: 07.09.19).

9. Информация о работе инспекторской группы Винницкого областного совета профсоюзов за второй квартал 1958 г. ЦДАВО України. Ф. 2605, оп. 8, спр. 1798.

10. Конституція (Основний Закон) Української Радянської соціалістичної республіки. Затверджено Постановою надзвичайного XIV Українського 3'їзду Рад від 30 січня 1937 p. URL: http://search.ligazakon.ua/__doc2.nsf/link1/ T370001.html (дата звернення: 06.09.19).

11. О контрольных цифрах развития народного хозяйства СССР на 19591965 гг. Доклад товарища Н. С. Хрущёва. Внеочередной ХХІ съезд Коммунистической партии Советского Союза. 27 января 1950 г. - 5 февраля 1959 г. Стенографический отчет. Т. 1. Москва: Госполитиздат, 1959. С. 12-120. 
12. О мерах по дальнейшему улучшению охраны труда на предприятиях и стройках. Постановление Совета Министров СССР и Всесоюзного Центрального Совета профессиональных союзов. 23 января 1962 г. № 73. Собрание постановлений правительства Союза Советских Социалистических республик. Москва: Госполитиздат, 1962. № 2. С. 23-27. (Далі: СПП СССР).

13. О мерах по улучшению состояния охраны труда и технике безопасности на железнодорожном транспорте. Постановление Совета Министров СССР от 21 февраля 1950 г. № 746. URL: http://www.libussr.ru/doc_ussr/ussr_477.htm (дата звернення: 07.09.19).

14. О передаче технической инспекции центральных комитетов профсоюзов и страховых врачей профсоюзных организаций в ведение советов профсоюзов. Постановление ВЦСПС от 17 августа 1957 г. Справочник профсоюзного работника. Москва: Профиздат, 1965. С. 227-229.

15. О повышении роли профсоюзов в хозяйственном строительстве. Постановление Пленума ЦК КПСС 16-17 декабря 1957 г. Коммунистическая партия Советского Союза в резолющиях и решениях съездов, конферениий и пленумов ЦК (1898-1986). Т. 9. 1956-1960. 9-е изд. доп. и испр. Москва: Политиздат, 1986. С. 215-228.

16. О порядке слияния Народного Комиссариата труда Союза ССР с Всесоюзным Центральным Советом профессиональных союзов. Постановление Совета Народных Комиссаров и Всесоюзного Центрального Совета профессиональных союзов. URL: http://www.libussr.ru/dok_ussr/ussr_3229.httm (дата звернення: 08.09.19).

17. Обучение кадров и профактива за 1963 г. Справка Укрсовпрофа. Центральний державний архів вищих органів влади і управління України. Ф. 2605, оп. 8, спр. 3657.

18. Отчёт о работе инспекторской группы Винницкого облсовпрофа за 1958 г. ЦДАВО України. Ф. 2605, оп. 8, спр. 1798.

19. Отчёт технической инспекции труда Днепропетровской, Запорожской, Донецкой областей за первую половину 1964. ЦДАВО Украӥни. Ф. 2605, оп. 8, спр. 4229; Справка о состоянии техники безопасности и производственного травматизма на предприятиях угольной промышленности. ЦДАГО України. Ф. 1, оп. 24, спр. 6080.

20. Отчётный доклад Центрального Комитета Коммунистической Советского Союза XX съезду партии. Доклад Первого секретаря ЦК КПСС тов. Н. С. Хрущева. ХХ съезд Коммунистической партии Советского Союза 1415 февраля 1956 г. Стенографический отчет. Т. І. Москва: Госполитиздат, 1956. C. 9-120. 
21. Положение о доверенных врачах советов профсоюзов и центральных комитетов профсоюзов. URL: http://ussdoc.com_communizm/ussr_5248.htm (дата звернення: 11.11.19).

22. Положение о комиссии охраны труда фабричного, заводского, местного (цехового) комитета профсоюза. Утверждено постановление Президиума ВЦСПС от 4 октября 1963 г. Справочник профсоюзного работника Москва: Профиздат, 1965. С. 261-263.

23. Положение о правах фабричного, заводского, местного комитета профессиональных союзов. Утверждено Указом Президиума Верховного Совета СССР от 15 июля 1958 г. Ведомости Верховного Совета СССР. 1958. № 15, ст. 282.

24. Положение о республиканском, краевом и областном совете профсоюзов. Постановление Президиума ВЦСПС от 17 августа 1957 г. Бюллетень Всесоюзного Центрального Совета профессиональных союзов. 1957. Август. № 16. С. 1-4. (Далі: Бюллетень ВЦСПС).

25. Программа Коммунистической партии Советского союза. Принята XXII съездом КПСС. ХХІІ съезд Коммунистической партии Советского Союза. 17 31 октября 1961 г. Стенографический отчет T. III. Москва: Политиздат, 1961. C. 229-335.

26. Протокол № 28 засідання президії Укрпрофради від 19 серпня 1955 р. ЦДАВО України. Ф. 2605, оп. 8, спр. 1033.

27. Протокол № 35 заседания президиума Украинского республиканского совета профсоюзов 19 декабря 1957 г. ЦДАВО Украӥни. Ф. 2605, оп. 8, спр. 1400. C. 255.

28. Семенков В. И. Охрана труда в СССР (правовые проблемы). В. И. Семенков. Избранные труды. Минск: Ред. журнала «Промышленно-торговое право», 2013. C. 14-460. URL: https://union.by/files/00214/obj/110/2283/doc/semenkovizbrannie trudi.pdf (дата звернення: 25.08.19).

29. Симород 3. К.Профспілки і трудові правовідносини (контрольні функції профспілок при встановленні і припиненні трудових правовідносин. Київ: Наукова думка, 1957. 159 с.

30. Соціальні трансформації: пізній сталінізм і хрущовська доба: монографія / кол. авт., відп. ред. В. М. Даниленко; ред.-упоряд. Н. О. Лаас. Київ: Інститут історії України НАН України, 2015. 698 с.

31. Среднегодовая численность рабочих и служащих по союзным республикам. Народное хозяйство СССР в 1963 г. Статистический ежегодник. Москва: Профиздат, 1965. С. 476.

32. Средние зарплаты в России и CСCР с 1897 по 2010 гг. (без автора). URL: http:// analysisclub.ru/index.php?page=schiller\&art=2757 (дата звернення: 24.09.2019). 
33. Статут професійних спілок. Затверджений ХІІ з'їздом профспілок СРСР 27 березня 1959 р. Київ: Політвидав України, 1959. 47 с.

34. Устав профессиональных союзов СССР. Утвержден ХІ съездом профсоюзов СССР 15 июня 1954 г. Москва: Профиздат, 1955. 31 с.

\section{References}

1. V CzK KPSS. Pis`mo Pervogo sekretarya CzK Kompartii Ukrainy`. P. E. Shelesta. 8 aprelya 1965 g. [In the CPSU Central Committee. Letter from the First Secretary of the Central Committee of the Communist Party of Ukraine. PE The sixth. April 8, 1965]. Czentral`nij derzhavnij arkhi`v gromads`kikh ob'yednan Ukrayini (CzDAGO Ukrayini). F. 1. Op. 24. Spr. 5990. S. 157-158.

2. Vystup Premier-ministra Ukrainy Oleksiia Honcharuka na kanali ICTV. 2 veresnia 2019 r. [Prime Minister of Ukraine Oleksiy Honcharuk's speech on ICTV on September 2, 2019]. URL: https://www.youtube.com/watch?V=rqqDqknFQU (data zvernennia: 14.09.19).

3. Gumenyuk A. A. Okhrana truda v SSSR v 1953-1985 gg. (po materialam Nizhnego Povolzh ya). [Labor protection in the USSR in 1953-1985 (on materials of the Lower Volga region]. Izvestiya Saratovskogo universiteta. Seriya Istoriya, Mezhdunarodny`e otnosheniya. 2015. № 1. S. 106-114. URL: http://nvsu.ru/ru/ otd_international/1967/1.pdf (data zvernennya: 03.09.19).

4. Danylenko V. M. Politychni zminy v SRSR i Ukraini v period khrushchovskoi «vidlyhy». Ukraina XX st.: kultura, ideolohiia, polityka. [Political changes in the USSR and Ukraine during the Khrushchev thaw. XX century Ukraine: culture, ideology, politics]. Kyiv: In-t istorii Ukrainy NAN Ukrainy, 2008. Vyp. 14, 3-17.

5. Danylenko V. M., Novokhatko L. M. Ekonomika Ukrainy v dobu destalinizatsii (1956-1965). Ekonomichna istoriia Ukrainy: Istoryko-ekonomichne doslidzhennia: v 2-kh t. [The Economy of Ukraine in the Age of De-Stalinization (1956-1965)]. NAN Ukrainy. Inctytut istorii Ukrainy. Kyiv: Nika-Tsentr, 2011. T. 2. S. 406-456.

6. Dokashenko V. M. «Vidlyha» v konteksti rozshyrennia prav i oboviazkiv profesiinykh spilok. [Thaw" in the context of the empowerment of trade unions]. Hrani istorii. Vyp. 8: zbirnyk naukovykh prats. Artemivsk: vyd-vo HIIM, 2015. S. 46-67.

7. Dokashenko V. M. Metamorfozy orhanizatsiinoi budovy radianskykh profspilok (seredyna 50-kh - seredyna 60-kh rr. [Metamorphoses of the organizational structure of the Soviet trade unions (mid 50's - mid 60's] Hrani istorii. Vyp. 6. Zbirnyk naukovykh prats. Horlivka: Vyd-vo HIIM «DDPU», 2013. S. 47-57.

8. Zhydetskyi V. Ts. Osnovy okhorony pratsi. Pidruchnyk. [Basics of labor protection. Textbook]. Lviv: Afiny, 2004. URL: https://westudents.com.ua/glavy/3379z-stor-naglyadu-za-ohoronoyu-prats-v-ukran.html (data zvernennia: 07.09.19). 
9. Informacziya o rabote inspektorskoj gruppy`Vinniczkogo oblastnogo soveta profsoyuzov za vtoroj kvartal $1958 \mathrm{~g}$. [Information on the work of the inspection team of the Vinnytsia Regional Trade Union Council for the second quarter of 1958]. CzDAVO Ukrayini. F. 2605. Op. 8. Spr. 1798.

10. Konstytutsiia (Osnovnyi Zakon) Ukrainskoi Radianskoi sotsialistychnoi respubliky. Zatverdzheno Postanovoiu nadzvychainoho KhIV Ukrainskoho Zizdu Rad vid 30 sichnia 1937 r. [Constitution (Basic Law) of the Ukrainian Soviet Socialist Republic]. URL: http://search.ligazakon. Ua/l_doc2.nsf/link1/T370001.html (data zvernennia: 06.09.19).

11. O kontrol`ny`kh czifrakh razvitiya narodnogo khozyajstva SSSR na 1959-1965 gg. Doklad tovarishha N. S. Khrushhyova. Vneocherednoj XXI s`ezd Kommunisticheskoj partii Sovetskogo Soyuza. 27 yanvarya 1950 g. -5 fevralya 1959 g. Stenograficheskij otchet. [On control figures for the development of the national economy of the USSR for 1959-1965. Report of Comrade N. S. Khrushchev]. T. 1. Moskva: Gospolitizdat, 1959. S. 12-120.

12. O merakh po dal'nejshemu uluchsheniyu okhrany` truda na predpriyatiyakh i strojkakh. [On measures to further improve labor protection at enterprises and construction sites]. Postanovlenie Soveta Ministrov SSSR i Vsesoyuznogo Czentral`nogo Soveta professional`ny`kh soyuzov. 23 yanvarya 1962 g. № 73. Sobranie postanovlenij pravitel'stva Soyuza Sovetskikh Soczialisticheskikh respublik. Moskva: Gospolitizdat, 1962. № 2. S. 23-27. (Dali`: SPP SSSR).

13. O merakh po uluchsheniyu sostoyaniya okhrany' truda i tekhnike bezopasnosti na zheleznodorozhnom transporte. Postanovlenie Soveta Ministrov SSSR ot $21 \mathrm{fev}$ ralya $1950 \mathrm{~g}$. № 746. [On measures to improve the state of labor protection and safety in railway transport]. URL: http://www.libussr.ru/doc_ussr/ussr_477.htm (data zvernennya: 07.09.19).

14. O peredache tekhnicheskoj inspekczii czentral`ny`kh komitetov profsoyuzov i strakhovy'kh vrachej profsoyuzny'kh organizaczij $\mathrm{v}$ vedenie sovetov profsoyuzov. Postanovlenie VCzSPS ot 17 avgusta 1957 g. (1965). [On the transfer of technical inspection of the central committees of trade unions and insurance doctors of trade union organizations to the councils of trade unions]. Spravochnik profsoyuznogo rabotnika. Moskva: Profizdat. S. 227-229.

15. O povy`shenii roli profsoyuzov v khozyajstvennom stroitel`stve. [On the increasing role of trade unions in economic construction]. Postanovlenie Plenuma CzK KPSS 16-17 dekabrya 1957 g. Kommunisticheskaya partiya Sovetskogo Soyuza v rezolyucziyakh i resheniyakh s`ezdov, konferenczij i plenumov CzK (18981986). T. 9. 1956-1960. 9-e izd., dop. i ispr. Moskva: Politizdat, 1986. S. 215-228.

16. O poryadke sliyaniya Narodnogo Komissariata truda Soyuza SSR s Vsesoyuzny`m Czentral`ny`m Sovetom professional`ny`kh soyuzov. Postanovlenie Soveta Narod- 
ny`kh Komissarov i Vsesoyuznogo Czentral nogo Soveta professional ny`kh soyuzov. [On the procedure for merging the People's Commissariat of Labor of the USSR with the All-Union Central Council of Trade Unions. Resolution of the Council of People's Commissars and the All-Union Central Council of Trade Unions]. URL: http://www.libussr.ru/do._ussr/ussr_3229.httm (data zvernennya: 08.09.19).

17. Obuchenie kadrov i profaktiva za $1963 \mathrm{~g}$. Spravka Ukrsovprofa. [Personnel and trade union training for 1963]. Czentral nij derzhavnij arkhi`v vishhikh organi`v vladi i` upravli`nnya Ukrayini. F. 2605. Op. 8. Spr. 3657.

18. Otchyot o rabote inspektorskoj gruppy`Vinniczkogo oblsovprofa za $1958 \mathrm{~g}$. [Report on the work of the inspection team of Vinnitsa Regional Trade Union in 1958]. CzDAVO Ukrayini. F. 2605. Op. 8. Spr. 1798.

19. Otchyot tekhnicheskoj inspekczii truda Dnepropetrovskoj, Zaporozhskoj, Doneczkoj oblastej za pervuyu polovinu 1964. [Report of the technical labor inspection of the Dnipropetrovsk, Zaporizhzhya, Donetsk regions for the first half of 1964]. CzDAVO Ukrayini. F. 2605. Op. 8. Spr. 4229.

20. Otchetnyi doklad Tsentralnoho Komyteta Kommunystycheskoi Sovetskoho Soiuza KhKh sъezdu partyy (1956). [Report of the Central Committee of the Communist Soviet Union to the Twentieth Party Congress]. Doklad Pervoho sekretaria TsK KPSS tov. N. S. Khrushcheva. XX syezd Kommunystycheskoi partyy Sovetskoho Soiuza 1-15 fevralia 1956 g. Stenohrafycheskyi otchet. T. I. Moskva: Hospolytyzdat. S. 9-120.

21. Polozhenye o doverennykh vrachakh sovetov profsoiuzov y tsentralnykh komytetov profsoiuzov [Regulations on trusted doctors of trade union councils and central trade union committees]. URL: http://ussdoc.com_communizm/ussr_5248.htm (data zvernennia: 11.11.19).

22. Polozhenye o komyssyy okhrany truda fabrychnoho, zavodskoho, mestnoho (tsekhovoho) komyteta profsoiuza. [Regulation on the labor protection commission of the factory, factory, local (workshop) committee of the trade union]. Utverzhdeno postanovlenye Prezydyuma VTsSPS ot 4 oktiabria $1963 \mathrm{~h}$. Spravochnyk profsoiuznoho rabotnyka. Moskva: Profyzdat, 1965. S. 261-263.

23. Polozhenye o pravakh fabrychnoho, zavodskoho, mestnoho komyteta professyonalnыkh soiuzov (1958) [Regulation on the rights of the factory, factory, local committee of trade unions]. Utverzhdeno Ukazom Prezydyuma Verkhovnoho Soveta SSSR ot 15 yiulia 1958 h. Vedomosty Verkhovnoho Soveta SSSR. № 15. St. 282.

24. Polozhenye o respublykanskom, kraevom y oblastnom sovete profsoiuzov. [Regulations on the republican, regional and regional council of trade unions]. Postanovlenye Prezydyuma VTsSPS ot 17 avhusta 1957 h. Biulleten Vsesoiuznoho Tsentralnoho Soveta professyonalnыkh soiuzov. 1957. Avhust. № 16. S. 1-4 (Dali: Biulleten VTsSPS). 
25. Prohramma Kommunystycheskoi partyy Sovetskoho soiuza. Pryniata KhKhII syezdom KPSS (1961) [The program of the Communist Party of the Soviet Union. Adopted by the XXII Congress of the CPSU]. XXII syezd Kommunystycheskoi partyy Sovetskoho Soiuza. 17-31 oktiabria $1961 \mathrm{~h}$. Stenohrafycheskyi otchet T. III. Moskva: Polytyzdat. S. 229-335.

26. Protokol № 28 zasidannia prezydii Ukrprofrady vid 19 serpnia 1955 r. [Minutes No. 28 of the Presidium of Ukrpofradi Vid 19 serpnia 1955 r.]. Tsentralnyi Derzhavnyi arkhiv vyshchykh orhaniv vlady ta upravlinnia Ukrainy. F. 2605. Op. 8. Spr. 1033.

27. Protokol № 35 zasedanyia prezydyuma Ukraynskoho respublykanskoho soveta profsoiuzov 19 dekabria 1957 h. [Minutes No. 35 of the meeting of the Presidium of the Ukrainian Republican Council of Trade Unions on December 19, 1957]. TsDAVO Ukrainy. F. 2605. Op. 8. Spr. 1400. S. 255.

28. Semenkov V. I. (2013) Okhrana truda v SSSR (pravovy`e problemy`) [Labor protection in the USSR (legal problems)]. V. I. Semenkov. Izbranny`e trudy`. Minsk: Red. zhurnala «Promy`shlenno-torgovoe pravo». S. 14-460. URL: https://union. by/files/00214/obj/110/2283/doc/semenkov_izbrannie_trudi.pdf (data zvernennya: 25.08.19).

29. Symorod Z. K. (1957) Profspilky i trudovi pravovidnosyny (kontrolni funktsii profspilok pry vstanovlenni i prypynenni trudovykh pravovidnosyn [Profiles and labor rights (control functions when installed and restrained labor rights]. Kyiv: Naukova dumka.

30. Sotsialni transformatsii: piznii stalinizm i khrushchovska doba. Kolektyvna monohrafiia (2015) [Social transformation: the rise of steel and Khrushchov extras. Collective monograph] / vidp. red. V. M. Danylenko; red.-uporiad. N. O. Laas. Kyiv: Instytut istorii Ukrainy NAN Ukrainy.

31. Srednegodovaya chislennost` rabochikh i sluzhashhikh po soyuzny`m respublikam. Narodnoe khozyajstvo SSSR v 1963 g. (1965) [The average annual number of workers and employees in the Union republics]. Statisticheskij ezhegodnik. Moskva: Profizdat. S. 476.

32. Srednie zarplaty` v Rossii [Average salaries in Russia and the USSR from 1897 to 2010 (without an author)] in SSSR s 1897 po 2010 g.' (bez avtora). URL: http:// analysisclub.ru/index.php?page $=$ schiller\&art $=2757$ (data zvernennya 24.09.201934)

33. Statut profesiinykh spilok (1959) [The charter of trade unions of the USSR]. Zatverdzhenyi KhII zizdom profspilok SRSR 27 bereznia 1959 r. Politvydav Ukrainy.

34. Ustav professional`ny`kh soyuzov SSSR (1955) [The charter of trade unions of the USSR]. Utverzhden KhI` s`ezdom profsoyuzov SSSR 15 iyunya 1954 g. Moskva: Profizdat. 